\title{
KEMATANGAN EMOSIONAL TERHADAP SISWA DISIPLIN DI SEKOLAH
}

\author{
Dwinda Tiara Putri \\ dwindataria_bk18s2@mahasiswa.unj.ac.id \\ Universitas Negeri Jakarta
}

\begin{abstract}
Abstrak
Disiplin selalu berkaitan dengan segala peraturan-peraturan dan adanya unsur-unsur yang berhubungan dengan pengontrolan pada tingkah laku seseorang. Disiplin disekolah merupakan ketaatan terhadap peraturan dan tata tertib yang harus ditaati oleh semua siswa, guru dan personil sekolah lainnya. Tanpa adanya peraturan dan tata tertib yang berlaku disekolah siswa tidak mempunyai pedoman apa uyang dianggap baik dan buruk dalam tindakan atau perilakunya. Kematangan emosional pada siswa mampu mengontrol dan mengendalikan emosinya dan tidak akan terpengaruh terhadap lingkungannya. Penelitian ini menggunakan pendekatan kuantitatif dengan metode deskriptif dan teknik pengumpulan data berupa angket bertipe ya dan tidak. Populasi yang diambil dalam penelitian ini adalah seluruh siswa/i kelas VIII SMPN 2 Tambun Selatan.
\end{abstract}

Kata Kunci: Emosional, Disiplin, Sekolah

\section{PENDAHULUAN}

Putaran kehidupan dunia yang penuh dengan gejolak berbagai perubahan diberbagai bidang menuntut semua manusia untuk berpacu dengan putaran tersebut. Kualitas sumber daya manusia menjadi penting dimiliki oleh setiap insan dan merupakan asset bagi sebuah Negara (state). Negara yang memiliki sumber daya manusia unggul bisa diprediksi akan tampil menjadi yang terdepan.

Indonesia sebagai bagian dari warga dunia dengan jumlah penduduk yang sangat besar merupakan Negara yang seharusnnya memiliki potensi untuk menjadi Negara paling terdepan persaingan perputaran kehidupan. Namun, kuantitas yang sangat besar tersebut bukanlah sebuah jaminan akan sebuah kualitas dalam pengambangan sumber daya manusia disebuah Negara (termasuk Indonesia). Dunia pendidikan salah satunya.
Berbagai kalangan telah sepakat bahwa dunia pendidikan nasional (sekolah dan luar sekolah) merupakan sebuah cara dan proses untuk menggapai pengembangan kualitas sumber daya manusia. Seperti yang tertera dalam Tujuan Pendidikan Nasional pada Bab II Pasal 4 sebagai berikut :

"Pendidikan nasional bertujuan mencerdasakan kehidupan bangsa dan mengembangkan manusia Indonesia seutuhnya yaitu manusia yang beriman, bertakwa kepada Tuhan Yang Maha Esa dan berbudi luhur, memiliki pengetahuan dan keterampilan, kesehatan jasmani dan rohani, kepribadian dan mandiri serta rasa tanggung jawab kemasyarakatan dan kebangsaan."

Untuk memenuhi tujuan pendidikan nasional tersebut sekolah cukup berperan dalam membina anak untuk menjadi orang dewasa yang bertanggung jawab. Sekolah 
yang merupakan lembaga pendidikan formal mempunyai peran yang sangat penting dan strategis dalam pembentukan kepribadian anak. Seperti yang dikemukakan oleh Sukmana dalam artikel di HU Pikiran Rakyat, edisi 3 September 2000 menulis bahwa didalam dan melalui sekolah siswa dididik sikap dan kepribadiannya, diajar berbagai ilmu pengetahuan untuk persiapan masa depannya. Begitu juga siswa dilatih psikomotoriknya, sehingga mempunyai keterampilan yang dapat diandalkan.

Dalam menjalankan perannannya sebagai lembaga pendidikan, sekolah mempunyai aturan yang harus dipatuhi oleh siswa, guru dan personil sekolah lainnya. Oleh karena itu siswa harus dapat memperlajari peraturan dan tata tertib yang berlaku dan dituntut untuk dapat bertingkah laku sesuai dengan peraturan sekolah yang telah ditetapkan.

Sunaryo Kartadinata (1983:151) mengemukakan bahwa tugas sekolah mencakup kemampuan berfikir logis, objektif, analtik dan mengembangkan kebutuhan untuk mengembangkan diri, pengembangan sistem nilai, kata hati, berdisiplin, tanggung jawab dan kehalusan perasaan. Dalam hal ini kualitas manusia yang diharapkan dari sekolah adalah kualitas manusia yang berdisiplin.
Dalam satu hasil penelitian komisi disiplin Phi Delta Kappa di Amerika Serikat yang dikemukakan oleh Wayson (A. Aco Agus, 000 : 6) membuktikan bahwa betapa pentingnya peranan sekolah dalam membentuk disiplin siswa. Dalam penelitian tersebut ditemukan bahwa sekolah yang baik adalah sekolah yang bercirikan : "membangun disiplin dengan cara menciptakan sekolah yang kondusif dalam menanamkan disiplin, terhindar dari praktek terisolasi yang berkenaan dengan masalah disiplin".

Keeratan hubungan konsep penanaman disipin dengan perilaku moral dijelaskan oleh Elizabeth B. Hurlock (1999:82) dalam bukunya perkembangan Anak, bahwa disiplin ialah seseorang yang berjalan dari atau secara sukarela mengikuti seorang pemimpin. Orang tua (keluarga) dan guru (sekolah) merupakan pemimpin dan anak merupakan murid yang belajar dari cara hidup yang berguna dan bahagia. Jadi, disiplin merupakan cara masyarakat mengajar anaknya memiliki perilaku kematangan emosional yang disetujui kelompok.

Salah satu dari contoh merosotnya disiplin dan moral tersebut diambil dari cerita siswa di SMP Negeri 2 Tambun Selatan, terdapat beberapa siswa yang sering terlambat kesekolah, sedangkan rumahnya tidak jauh dari sekolah dan 
tidak mengerjakan tugas (PR). Sepenggal kisah diatas merupakan hanya salah satu masalah merosotnya sikap disiplin yang mungkin pada gilirannya nanti akan berdampak pada rusaknya perilaku moral siswa

Oleh karena itu pentingnya dunia pendidikan (sekolah) sebagai komponen penopang pengembangan sumber daya manusia dikemudian hari telah melahirkan sebuah keprihatinan untuk "melihat sisi lain" yang terdalam dari sebuah gejala merosotnya disiplin dan tanda-tanda kurang matangnya emosional siswa SMP di Kab. Bekasi untuk dilakukan sebuah riset mengenai disiplin dalam membentuk sebuah perilaku kematangan emosional dengan fokus objek di SMP Negeri 2 Tambun Selatan.

\section{Siswa yang Disiplin}

Salah satu unsur pokok yang harus diperhatikan dalam proses pendidikan di sekolah adalah upaya sekolah menjadikan siswa berpribadi sehat, yang memiliki kemampuan untuk menyesuaikan diri secara tepat, baik terhadap dirinya maupun terhadap lingkungannya. Salah satu ciri pribadi yang sehat adalah disiplin.

Disiplin senantiasa berkaitan dengan segala peraturan-peraturan dan adanya unsur-unsur yang berhubungan dengan pengontrolan tingkah laku. Apabila kita berbicara mengenai disiplin maka selalu akan dihubungkan dengan cara-cara pengendalian tingkah laku dari luar (Singgih D. Gunarsa, 1987 : 138). Selanjutnya D. Soemarmo (1996 : 29), mengemukakan :

Disiplin adalah ketaatan terhadap peraturan dan norma kehidupan bermasyarakat, berbangsa dan bernegara yang berlaku, yang dilaksanakan secara sadar dan ikhlas lahir dan batin, sehingga timbul rasa malu terhadap sanksi dan rasa takut terhadap Tuhan Yang Maha Esa.

Di sekolah terdapat sejumlah aturan dan tata tertib yang harus ditaati oleh semua siswa, guru dan personil sekolah lainnya. Tanpa adanya aturan dan tata tertib tersebut siswa tidak mempunyai pedoman apa yang dianggap baik dan buruk dalam tindakan atau perilakunya. Aturan atau tatatertib yang berlaku disekolah tersebut kita kenal dengan peraturan sekolah.

A.Aco Agus (2000 : 11) berpendapat Peraturan sekolah adalah tatanan atau sesuatu yang dibuat untuk tata tertib sekolah, baik ketentuan-ketentuan tertulis (tata tertib sekolah), yang mengatur tugas dan kewajiban siswa dilingkungan sekolah maupun ketentuan-ketentuan tidak tertulis (tata krama) yang mengatur cara-cara bergaul dilingkungan sekolah. 


\section{Kematangan Emosional}

Kematangan emosional pada siswa di sekolah diharapkan mampu membantu untuk hidup bermasyarakat dan mengembangkan pola perilaku yang sesuai dengan norma, nilai-nilai moral dan tatanan sosial yang terdapat dimasyarakat. Pola perilaku yang dapat dikatakan sesuai dengan nilai-nilai moral tersebut dengan perilaku moral.

Perilaku moral menurut Elizabeth B. Hurlock (1999 : 74) mengemukakan: Perilaku moral berarti perilaku yang sesuai dengan kode moral kelompok sosial, perilaku moral yang dikendalikan konsep-konsep moral, peraturan perilaku yang telah menjadi kebiasaan bagi anggota suatu budaya dan yang menentukan pola perilaku yang diharapkan dari seluruh anggota kelompok.

Sedangkan menurut Yulia Singgih D. Gunarsa (2002 : 69) mengatakan : Perilaku moral terdiri dari kumpulan tingkah laku seseorang yang dilakukan sesuai dengan peraturan-peraturan yang diamalkan dalam suatu suasana/keadaan sosial tertentu. Perilaku moral terdiri dari perilaku yang disenangi, seperti kepatuhan, berbicara jujur, membagi, menipu, berbohong dan memberontak.

Mampu mengontrol dan mengendalikan emosinya, tidak mudah terpengaruh oleh lingkungan luar maupun dalam dirinya, menerima kritikan dan mampu menyalurkan emosinya ke hal yang positif. Kematangan emosi juga dapat dipengaruhi oleh lingkungannya, baik lingkungan keluarga, social, maupun lingkungan sekolah.

\section{PEMBAHASAN}

\section{Pengertian Emosi}

Emosi dilihat dalam psikologi yang dialami oleh seseorang meliputi perasaan kesedihan, kemarahan, kebahagian, rasa takut dan lainnya. Dan emosi berperan penting dalam kehidupan diri manusia karena emosi adalah ekspresi diri yang dikeluarkan oleh manusia dalam bertindak dilingkungan sosialnya.

Para ahli psikologi mendefinisikan emosi dengan berbagai tinjauan, keberadaan emosi sendiri merupakan peranan penting dalam setiap individu dalam kehidupan ini. Dari segi etimologi emosi berasal dari kata bahasa latin "emovere" yang berarti menggerakkan, "move" yang berarti bergerak dan "e" yang memberi arti bergerak menjauh (Darwis : 2006).

Menurut Daniel Goleman (1995) seorang tokoh psikologi kecerdasan emosional mengemukakan istilah emosional yang diambil dari Oxford English Dictionary yaitu emosi adalah suatu keadaan biologis dan psikologis 
berupa perasaan yang meluap-luap seperti pikiran, perasaan dan nafsu dan kecendrungan untuk bertindak.

Emosional pada diri seseorang akan terus berkembang seiring dengan bertambahnya usia. Perkembangan emosional akan melewati beberapa fase yang didukung oleh faktor pendukung, yaitu faktor eksternal dan internal. Faktor internal misalnya diri sendiri, usia dan lingkungan keluarga, sedangkan faktor eksternal seperti pasangan (suami-istri), teman sebaya, lingkungan kerja dan masyarakat (Sumitro: 2012).

Jadi dapat disimpulkan emosi adalah suatu perasaan yang dialami seseorang yang ditandai dengan perubahanperubahan presepsi, sikap, tingkah laku dan perubahan jiwa/raga lainnya. Emosi dirasakan secara psikofisik karena terkait langsung dengan jiwa dan fisik. Ketika seseorang mengalami perasaan emosi bahagia yang menggebu-gebu ia secara psikis merasa puas, akan tapi secara fisiologis membuat jantung terasa berdebar-debar. Dan kadang membuat seseorang berteriang kegirangam, namun tidak semua orang merasakan hal yang sama.

\section{Kematangan Emosional}

Anderson (dalam Mappiare, 1983:

18) berpendapat bahwa seseorang yang mampu mengendalikan emosinya dan mampu berfikir baik berarti orang tersebut dapat dikatakan sudah dewasa, tetapi orang dewasa belum tentu dapat mengendalikan emosi yang dimilikinya dengan baik. Menurut Kartono (1995: 165) kematangan emosi adalah seseorang dapat dikatakan dewasa jika mampu mencapai fase perkembangan emosional yaitu ia mampu menggunakan emosinya dengan baik. Menurut Davidoff (1991: 49) kematangan emosi yaitu seseorang yang mampu mengalihkan emosinya dan menyalurkan emosinya kearah yang lebih baik dan dapat bermanfaat. Hurlock (1999: 213) berpendapat bahwa kematangan emosi adalah kondisi dimana seseorang mampu menahan emosinya di hadapan orang lain dan mampu mengungkapkan emosinya dengan tindakan yang tepat sehingga dapat diterima oleh orang lain.

Sartre (2002: 7) menerangkan bahwa kematangan emosi adalah seseorang dapat bertindak dengan tepat dan wajar sesuai dengan keadaan dan kondisi meskipun pada situasi yang terganggu yang berasal dari dalam dirinya maupun dari luar.

Jadi dapat disimpulkan bahwa kematangan emosional adalah suatu perasaan yang dapat dikendalikan dan diorganisir oleh seseorang, ia dapat mengendalikan emosi dan 
mengalihkannya kearah yang lebih positif, bertanggung jawab untuk memberikan tanggapan yang baik dalam menghadapi tantangan hidup, menerima keadaan dirinya, dan mampu berpikir objektif.

\section{Ciri-ciri Kematangan Emosional}

Menurut Walgito (2004: 43) orang yang matang emosinya mempunyai ciriciri antara lain:

a. Dapat menerima keadaan dirinya maupun orang lain sesuai dengan objektifnya.

b. Pada umumnya tidak bersifat impulsive, dapat mengatur pikirannya dalam memberikan tanggapan terhadap stimulus yang mengenainya.

c. Dapat mengontrol emosinya dengan baik dan dapat mengontrol ekspresi emosinya walaupun dalam keadaan marah dan kemarahan itu tidak ditampakkan keluar.

d. Dapat berpikir objektif sehingga akan bersifat sabar, penuh pengertian dan cukup mempunyai toleransi yang baik.

e. Mempunyai tanggung jawab yang baik, dapat berdiri sendiri, tidak mengalami frustrasi dan mampu menghadapi masalah dengan penuh penngertian.

Ciri-ciri kematangan emosi menurut Anderson (dalam Mappiare, 1983: 153), yaitu: a. Kasih sayang: individu mempunyai rasa kasih sayang seperti yang didapatkan dari orang tua atau keluarganya sehingga dapat diwujudkan secara wajar terhadap orang lain sesuai dengan norma sosial yang ada.

b. Emosi terkendali: individu dapat menyetir perasaan-perasaan terutama terhadap orang lain, dapat mengendalikan emosi dan mengekspresikan emosinya dengan baik.

Emosi terbuka, lapang: individu menerima kritik dan saran dari orang lain sehubungan dengan kelemahan yang diperbuat demi pengembangan diri, mempunyai pemahaman mendalam tentang keadaan dirinya.

Dan dapat disimpulkan bahwa ciriciri dari kematangan emosional yaitu seseorang dapat menerima dirinya, mampu mengendalikan emosi yang muncul dari dalam dirinya, berfikir obejektif dengan baik dan mampu menghadapi masalah dengan penuh pengertian.

\section{Faktor-faktor Kematangan Emosi}

Menurut Schneider

(1964) tercapainya kematangan emosi didukung oleh kesehatan fisik yang berhubungan dengan kesehatan emosi dan penyesuaian emosi. Sedangkan menurut Young (1950) 
factor-faktor yang mempengaruhi kematangan emosi yang lain adalah (dalam Fema: http:/www.hubungan kematangan emosi terhadap konformitas pada remaja.com) :

a. Faktor lingkungan yaitu adanya faktor lingkungan individu, misalnya lingkungan yang tidak aman akan mempengaruhi emosinya.

b. Faktor pengalaman yaitu bagaimana pengalaman hidup individu yang telah memberikan masukan nilai-nilai dalam kehidupan.

c. Faktor individu yaitu factor-faktor yang terdapat dalam diri individu itu sendiri, contohnya bagaimana kepribadiannya.

Menurut Hurlock (1980) hal-hal yang dapat memengaruhi kematangan emosi adalah :

a. Gambaran tentang situasi yang dapat menimbulkan reaksi-reaksi emosional.

b. Membicarakan berbagai masalah pribadi dengan orang lain.

c. Lingkungan sosial yang dapat menimbulkan perasaan aman dan keterbukaan dalam hubungan social.

d. Belajar menggunakan katarsis emosi untuk menyalurkan emosi.

e. Kebiasaan dalam memahami dan menguasai emosi dan nafsu (Fitria : 2010)
Faktor-faktor kematangan emosi yang memengaruhi kematangan emosi adalah : faktor lingkungan sosial yang memberikan kenyaman dan keamanan, faktor pengalaman yang memberikan nilai-nilai pada kehidupan, dan faktor dari individu itu sendiri kepribadiannya, fisik dan emosional yang dimilikinya.

\section{Aspek-aspek Kematangan emosional}

Dr. Fadil (Wardani, 2011) mengatakan aspek-aspek kematangan emosi antara lain :

a. Realitas, berbuat sesuai dengan kondisi, mengetahui dan menafsirkan permasalahan tidak hanya satu sisi.

b. Mengetahui mana yang harus di dahulukan, mampu menimbang dengan baik diantara beberapa hal dalam kehidupan. Mengetahui mana yang terpenting diantara yang penting. Tidak mendahulukan permasalahan yang kecil dan mengakhiri masalah yang besar.

c. Mengetahui tujuan jangka panjang, diwujudkan dengan kemampuan mengendalikan keinginan atau kebutuhan demi kepentingan yang lebih penting ada masa yang akan datang.

d. Menerima tanggung jawab dan menunaikan kewajiban dengan teratur, optimis dalam melakukan 
tugas, dan mampu hidup di bawah aturan tertentu.

e. Menerima kegagalan, bisa menyikapi kegagalan dan dewasa dalam menghadapi segala kemungkinan yang tidak menentu guna mencapai sebuah kemakmuran, serta mencurahkan segala potensi guna mencapai tujuan.

f. Hubungan emosional. Seseorang tidak hanya mempertimbangkan diri sendiri tapi mulai membiarkan perhatiannya pada orang lain. Pencarian yang serius tentang jati diri serta komunitas sosial.

Bertahap dalam memberikan reaksi. Mampu mengendalikan saat kondisi kejiwaan memuncak.

\section{Disiplin}

Disiplin merupakan modal utama untuk mengatur efektivitas dan efisiensi pencapaian cita-cita individu. Orang yang berdisiplin akan hidup teratur, peka terhadap perkembangan zaman dan mempunyai etos kerja dan etos hidup yang mapan.

Disiplin berasal dari kata "Disciple" yakni seseorang yang belajar dari atau secara sukarela mengikuti seorang pemimpin (Elizabeth B. Hurloc, 1999 : 82). Lebih jelasnya disiplin adalah suatu keadaan tertib dimana para penganut (pengikut) tunduk terhadap ajaran pemimpinnya (A. Aco Agus, 2000 : 31). Victor M. Situmorang dan Yusuf Sahir (1993 : 127) mengartikan disiplin sebagai berikut: Disiplin adalah ketaatan, kepatuhan dalam mengormati dan melaksanakan suatu sistem yang mengharuskan orang tunduk pada putusan perintah atau peraturan yang berlaku.

Lindgren (Syamsu Yusuf LN, 1989 :

21) mengemukakan bahwa ada tiga pengertian mengenai disiplin, yaitu :

a. Punishment (hukuman) :

Hal ini berarti anak perlu dihukum (bila salah)

b. Control by enforcing obedience or orderly conduct :

Hal ini berarti anak memerlukan seseorang yang mengontrol, mengarahkan dan membatasi tingkah lakunya.

c. Training that correct and strengthness

Memberikan kesempatan kepada individu untuk melakukan sesuatu berdasarkan pengarahan dan kontrol dirinya.

Dapat disimpulkan bahwa disiplin merupakan cara masyarakat atau suatu keadaan yang telah ditetapkan oleh masyarakat untuk mengajar anak perilaku moral yang disetujui oleh kelompok. 
Elizabeth B. Hurlock (1999:84) mengemukakan unsure-unsur pokok disiplin, yaitu :
a. Peraturan
b. Hukuman
c. Penghargaan
d. Konsistensi

Macam-macam disiplin menurut Elizabeth B. Hurlock (1999 : 82) yaitu disiplin internal dan disiplin eksternal. Yang berasal dari dalam diri adalah disiplin yang positif sama dengan disiplin diri, lebih mengarahkan untuk memotivasi diri dan melakukan sesuai dengan kesadaran diri sendiri. Disiplin eksternal adalah disiplin negative yang berhubungan denga kontrol dan otoritas pihak luar, yang biasanya dilakukan secara terpaksa dengan cara yang tidak menyenangkan. Faktor-faktor yang mempengaruhi disiplin adalah pendidikan dikeluarga, pendidikan sekolah dan pendidikan didalam masyarakat.

Penanaman disiplin oleh sekolah dengan menerapkan prinsip-prinsip penanaman disiplin yang dilakukan oleh guru disekolah akan mempengaruhi proses pendidikan yang memadai. Penanaman disiplin pada dasarnya dapat diklasifikasikan kedalam tiga tipe, yaitu :

a. Otoriter, ciri-cirinya :

1) Guru menerapkan peraturan tanpa kompromi a) Guru lebih mendominasi atau mengusai siswa

b) Menentukan dan mengatur kelakuan siswa,

c) Merasa berkuasa dan berhak memberikan perintah, larangan dan hukuman, (S. Nasution, 1995 : 132).

2) Guru mengukum siswa yang tidak mentaati peraturan

3) Guru tidak memberikan kesempatan kepada siswa untuk mengemukakan pendapat atau meminta bantuan dalam memecahkan masalah yang dihadapinya.

b. Demokratis, ciri-cirinya :

Mengadakan dialog dengan siswa, memberikan bantuan kepda siswa yang menghadapi masalah, guru menghargai siswa, guru memberikan kesempatan kepada siswa untuk mengemukakan pendapat.

c. Laissez Faire, ciri-cirinya :

Guru bersikap acuh tak acuh terhadap kepentingan siswa dan memberikan kesempatan kepada siswa untuk mengontrol dirinya sendiri.

Langkah-langkah untuk menanamkan disiplin pada siswa disekolah dengan guru menjadi contoh dan teladan untuk siswa, anjuran untuk melakukan sesuatu yang berguna, memberitahukan siswa pada norma yang 
melarang perilaku yang dapat mengambat proses pendidikan, pembiasaan menekankan ketertiban dan keteraturan dalam setiap pekerjaan siswa sehingga akan tertanam pada diri siswa kebiasaankebiasan yang baik, memberikan teguran, peringatan, peringatan, larangan, ganjaran dan hukuman.

Jadi dalam penanaman disiplin siswa menurut penulis sebaiknya dilakukan melalui tata tertib sekolah, perlu adanya pendekatan langsung yakni pendekatan yang diberikan secara pribadi kepada siswa itu sendiri dan pendekatan tidak langsung adalah pendekatan yang diberikan melalu kelompok kecil, memberikan wejangan secara umum tentang tata tertib, memperkuat motivasi atau dorongan, mengadakan diskusi kelompok dengan memberikan kesempatan kepada siswa untuk mengemukakan pendapat dan pandangan, melakukan permainan bersama.

Disiplin menurut penulis adalah serangkaian perilaku dalam diri untuk mematuhi peraturan, menunjukan nilainilai ketaatan, kesetiaan, keteraturan dan ketertiban. Dan mampu mengendalikan sikap yang berasal dari dalam maupun luar dari dirinya. Disiplin diri ialah kesadaran diri seseorang untuk berperilaku bijak akan tugas dan tanggung jawabnya.

\section{Hubungan Kematangan Emosional dengan Disiplin di Sekolah}

Salah satu unsur pokok yang amat penting untuk diperhatikan dalam proses pendidikan adalah bagaimana agar siswa dapat menjadi seseorang yang berkepribadian disiplin, yang memiliki kemampuan untuk menyesuaikan diri secara tepat, baik terhadap dirinya sendiri, lingkungan maupun terhadap Tuhan.

Disiplin memberikan manfaat bagi siswa menjadi lebih terarah dan lebih matang dalam bertindak. Tetapi disiplin yang terlalu ketat akan mematikan kreatifitas siswa untuk berkembang karena hanya akan berbuat apabila diperintah saja.

Siswa yang disiplin akan memiliki perilaku kematangan emosional sadar akan peraturan, norma-norma yang ada di lingkungannya, sadar dengan kewajiban atau larangan untuk dilakukan dan yang tidak. Mengerti akan tindakan yang akan diperbuat akan ada hasil baik atau buruk yang dapat diperolehnya

Dapat memotivasi diri sendiri, perilaku untuk disiplin dilaksanakan dengan sukarela tanpa paksaan, lebih mengutamakan kepentingan umum daripada kepentingan pribadi, mampu mengendalikan emosinya kearah yang lebih positif, mampunya memberikan aura positif bagi teman dan lingkungannya. 


\section{METODOLOGI PENELITIAN}

\section{Subjek Penelitian}

Uji coba instrument dilakukan terhadap siwa/i kelas II SMPN 2 Tambun Selatan 1 tahun ajaran 2018/2019, jumlah dari keseluruhan siswa kelas II di SMPN 2 Tambun Selatan adalah 439 siswa dari 12 kelas. Karena jumlah populas yang kurang dari 1000 orang, maka penulis mengambil $15 \%$ dari jumlah populasi yaitu sebesar 64 orang, hal ini sejalan dengan pendapat yang dikemukakan oleh Winarno Surachmad (1994:110) : "Bila populasi atau sama dengan 100 dapat dipergunakan sampel sebesar 50\%, sedangkan apabila populasi sama dengan atau kurang dari 1000 maka sampel yang diambil sekurang-kurangnya $15 \%$ dari populasi.

\section{Pengumpulan Data}

Pengumpulan data ini dilakukan dengan langkah-langkah sebagai berikut :

a. Membagikan alat pengumpulan data

b. Memberikan petunjukan cara pengisian alat pengumpulan data tersebut

c. Mengumpulkan hasil kerja responden

d. Mengecek kelengkapan identitas dan jawaban responden pada lembar jawaban

\section{Proses Penelitian}

Secara garis besar proses yang dilakukan dalam penelitian ini adalah sebagai berikut :

\section{Pengembangan Instrumen}

Subjek instrument adalah siswa/i kelas VIII SMPN 2 Tambun Selatan tahun ajaran 2018/2019. Model skala yang dikembangkan adalah angket bersekala "Ya" atau "Tidak". Pernyataan dalam angket berbentuk positif dan negative dengan system penyekiran sebagai berikut:

Table 1. Ketentuan Pemberiaan Skor Kematangan Emosional pada Siswa yang Disiplin di Sekolah

\begin{tabular}{|c|c|c|}
\hline Arah Penyataan & Ya & Tidak \\
\hline Positif & 1 & 0 \\
\hline Negatif & 0 & 1 \\
\hline
\end{tabular}

Angket yang akan dibagikan, yaitu angket mengenai kematangan emosional terhadap siswa disiplin disekolah. Didalam angket siswa diminta untuk menilai diri sendiri sejauh mana dalam melaksanan tata tertib sekolah tersebut, serta apakah perilakunya sudah sesuai dengan pernyataan yang ada di dalam angket tersebut.

\section{Penilaian/Penelitian Terhadap Setiap \\ Butir Pertanyaan \\ Penilaian bertujuan untuk melihat kesesuaian antara isi rumusan setiap pernyataan dengan indikator nilai yang diukur oleh butir penyataan itu berdasarkan konstruk variabelnya.}




\section{Perakitan Pernyataan}

Dari hasil penilaian diatas maka jumlah butir soal dari instrument kematangan emosional siswa yang dapat di uji cobakan sebanyak 30 butir soal.

\section{Prosedur Pengolahan Data Penelitian}

Pengolahan data dan analisis data dilakukan dengan bantuan program SPSS (statistical packages for social science)

\section{Pengujian Validitas dan Realibitas Instrumen Penelitian}

Pengujian validitas setiap item pernyataan dengan menggunakan rumus koreasi point biserial.

\section{e. Validitas}

Validitass berasal dari kata validity yang berarti sejauh mana ketepatan dan kecermatan suatu instrument pengukur (test) dalam melakukan fungsi ukurannya (Azwar, 2012). Definisi lain dari validitas adalah ketepatan atau kecermatan suatu instrument dalam mengukur apa yang ingin diukur (Suryabrata, 2005)

\section{f. Realibitas}

Realibitas diterjemahkan dari kata Realibity, mengacu pada keterpercayaan atau konsistensi hasil ukur, yang mengandung makna seberapa tinggi kecermatan pengukuran. Hasil ukur dapat dipercaya apabila dalam beberapa kali pengukuran terhadap kelompok subjek yang sama diperoleh hasil yang relative sama, selama aspek yang diukur dalam diri subjek memang belum berubah (Azwar, 2012).

\section{Penyekoran data}

Penyekoran terhadap jawaban tiap responden dilakukan dengan menjumlahkan skor yang diperoleh siswa, dengan mengacu pada pola penyekoran skor yang telah ditetapkan

\section{HASIL PENELITIAN}

\section{Hasil penelitian}

Berdasarkan penelitian dan langkahlangkah pengolahan data, maka hasil penelitian digambarkan sebagai berikut :

Tabel 2. Gambaran Perilaku Kematangan

Emosional Siswa Kelas VIII SMP N 2

Tambun Selatan

\begin{tabular}{|c|c|c|c|}
\hline Kategori & $\begin{array}{c}\text { Rentang } \\
\text { Skor }\end{array}$ & $\begin{array}{c}\text { Frekwe } \\
\mathrm{nsi}\end{array}$ & $\begin{array}{c}\text { Presentas } \\
\mathrm{e}\end{array}$ \\
\hline Baik & $\mathrm{X} \geq 16$ & 42 & $63.64 \%$ \\
\hline Cukup & $8 \leq \mathrm{X}<16$ & 20 & $30.30 \%$ \\
\hline Kurang & $\mathrm{X}<8$ & 4 & $6.06 \%$ \\
\hline
\end{tabular}

Table diatas menunjukan bahwa $63.64 \%$ perilaku kematangan moral siswa baik, $30.30 \%$ cukup baik dan $6.06 \%$ kurang. 


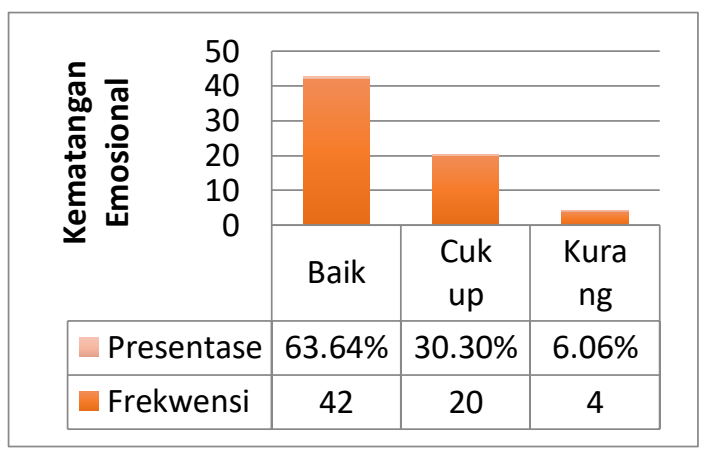

Grafik 1 Perilaku Kematangan Emosional

Siswa Kelas VIII SMP N 2 Tambun

Selatan

\section{Pembahasan Hasil Penelitian}

Hasil penelitian menunjukan sebesar $63.64 \%$ siswa yang berperilaku memiliki kematangan emosional dengan baik, $30.30 \%$ siswa yang memiliki kematangan emosional cukup baik serta $6.06 \%$ siswa yang kurang memiliki kematangan emosional. Perilaku moral baik dalam penelitian ini berarti siswa telah berperilaku sesuai dengan ketentuanketentuan dan kebiasaan-kebiasaan yang berlaku disekolah.

\section{KESIMPULAN}

Berdasarkan hasil penelitian dan pembahasan pada bab sebelumnya, didapatkan kesimpulan sebagian siswa kelas VIII SMPN 2 Tambun Selatan memiliki kematangan emosional terhadap kedisiplinan yang ada di lingkungan sekolah.

\section{DAFTAR PUSTAKA}

Arikunto, Suharsimi. (2006). Prosedur Penelitian Suatu Pendekatan Praktik. Jakarta: Rineka Cipta.
Depdiknas. (2007). Rambu-rambu Penyelenggaraan Bimbingan dan Konseling dalam Jalur Pendidikan Formal.

Direktorat Jenderal Peningkatan Mutu Pendidikan dan Tenaga Kependidikan Depdiknas. (2007). Diktat Instruktur Tingkat Lanjutan Guru Pembimbing SMA. Depdiknas.

Depdiknas. (2008). Penataan Pendidikan Profesional Konselor dan Layanan Bimbingan dan Konseling dalam Jalur Pendidiakan Formal. Jakarta: Depdiknas.

Diastuti, D., Rangka, I. B., Prasetyaningtyas, W. E., \& Renata, D. (2017). Hubungan Persepsi Dengan Motivasi Siswa Sekolah Menengah Kejuruan Dalam Konseling Perorangan. JURKAM: Jurnal Konseling Andi Matappa, 1(2), 116- 124.

Isjoni. (2007). Pengaruh Gaya Kepemimpinan Kepala Sekolah dan Kinerja Guru di SLTP Negeri Tenggarong Kalimantan Timur. Jurnal Kinerja Guru.Yogyakarta : Pascasarjana UNY.

Moh. Nazir. (2003). Metode Penelitian. Jakarta: Ghalia Indonesia.

Moh. Nazir. (2005). Metode Penelitian. Jakarta: Ghalia Indonesia.

Nawawi, Hadari. (2007). Metode Penelitian Bidang Sosial. (Cetakan ke- 11). Yogyakarta: Gajah Mada University Press.

Oktasari, M. (2017). Perceptions around teacher's social support with student achievement motivation. TERAPUTIK: 
Jurnal Bimbingan dan Konseling, 1(2), 145- 150.

Sudrajat Ahmad. (2008). Peranan Kepala Sekolah, Guru, dan Wali Kelas Dalam Bimbingan Konseling. Sukardi, (2009). Metodologi Penelitian

Pendidikan Kompetensi dan Praktiknya. Jakarta: PT Bumi Aksara.

Santiasa, I Wayan. (2009). Metode Penelitian Pengembangan dan Pengembangan

Modul.Universitas Pendidikan Ganesha

Purwanto. (2007). Instrumen Penelitian Sosial dan Pendidikan Pengembangan dan Pemanfaatan. Yogyakarta: Pustaka Pelajar.

Permendiknas Nomor 13 Tahun 2007 tentang Standar Kepala Sekolah/ Madrasah

Permendikbud Nomor 111 Tahun 2014 tentang Bimbingan dan Konseling di sekolah menengah dan dasar.

Rahmat, J. (2000). Psikologi Komunikasi. Bandung: Remaja Rosdakarya.

Saifudin Azwar . (1999). Penyusunan Skala Psikologi . Yogyakarta: Pustaka Pelajar.

Sarwono, Sarlito. (2002). Pengantar Psikologi Umum. Jakarta: Rajawali Press

Sarwono, Sarlito Wirawan. (1999). Psikologi Sosial. Jakarta: Balai Pustaka
Slameto. (2003). Belajar dan Faktorfaktor yang Mempengaruhinya. Jakarta: Rineka Cipta.

Sobur, Alex. (2003). Psikologi Umum. Bandung: Pustaka Setia

Suharnan. (2005). Psikologi Kognitif. Surabaya: Srikandi

Sugiyono Shaleh, Abdul Rahman. (2007). Psikologi Suatu Pengantar Dalam Perspektif Islam. Jakarta: Kencana

Tohirin. (2007). Bimbingan dan Konseling di Sekolah dan Masdrasah (berbasis integrasi). Jakarta: PT. RajaGrafindo Persada.

W.S. Winkel dan M.M Sri Hastuti. (2004). Bimbingan dan konseling di institusi pendidikan.Yogyakarta:Media Abadi 